\title{
A PUZZLING BODY FROM THE RIVER THAMES IN LONDON
}

\author{
Alex Bayliss $^{1,2} \cdot$ Peter Marshall $^{1,3} \cdot$ Jane Sidell $^{4}$
}

ABSTRACT. Radiocarbon measurements on a partially articulated female human skeleton, recovered from the foreshore of the river Thames in London, raised interesting questions of interpretation when the body did not produce the anticipated Neolithic date. A relatively recent ${ }^{14} \mathrm{C}$ age and a strong marine component to the individual's diet, identified by stable isotope measurements, means that the date of death is difficult to estimate accurately, although the body probably does not constitute a forensic case.

\section{INTRODUCTION}

In February 2002, a partial, articulated, female human skeleton was recovered from the eroding foreshore of the river Thames downstream of Tower Bridge close to Chamber's Wharf (Figure 1; NGR, TQ $5343017975 ; 53^{\circ} 56^{\prime} 24^{\prime \prime} \mathrm{N}, 00^{\circ} 11^{\prime} 20^{\prime \prime} \mathrm{W}$ ). The body was apparently associated with twigs, 6 fragments of Peterborough Ware pottery, and characteristic Neolithic flintwork (Figure 2). Radiocarbon dating was undertaken to confirm the suspected Neolithic date of this burial, and to determine whether she is the earliest Londoner so far discovered.

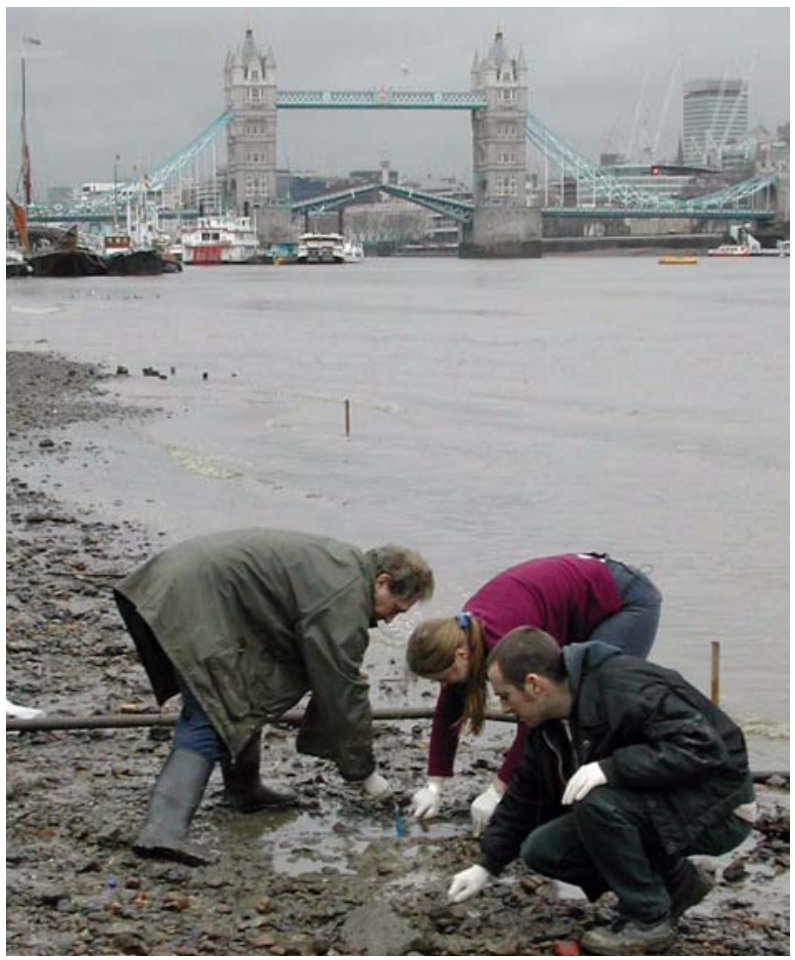

Figure 1 Excavating the skeleton on the foreshore

\footnotetext{
${ }^{1}$ English Heritage, 23 Savile Row, London, W1S 2ET, United Kingdom.

${ }^{2}$ Corresponding author. Email: alex.bayliss@english-heritage.org.uk.

32Email: peter.marshall@english-heritage.org.uk.

${ }^{4}$ Institute of Archaeology, University College London, 31-34 Gordon Square, London, WC1H 0PY, United Kingdom. Email: j.sidell@ucl.ac.uk.
}

(C) 2004 by the Arizona Board of Regents on behalf of the University of Arizona

Proceedings of the 18th International Radiocarbon Conference, edited by N Beavan Athfield and R J Sparks RADIOCARBON, Vol 46, Nr 1, 2004, p 285-291 


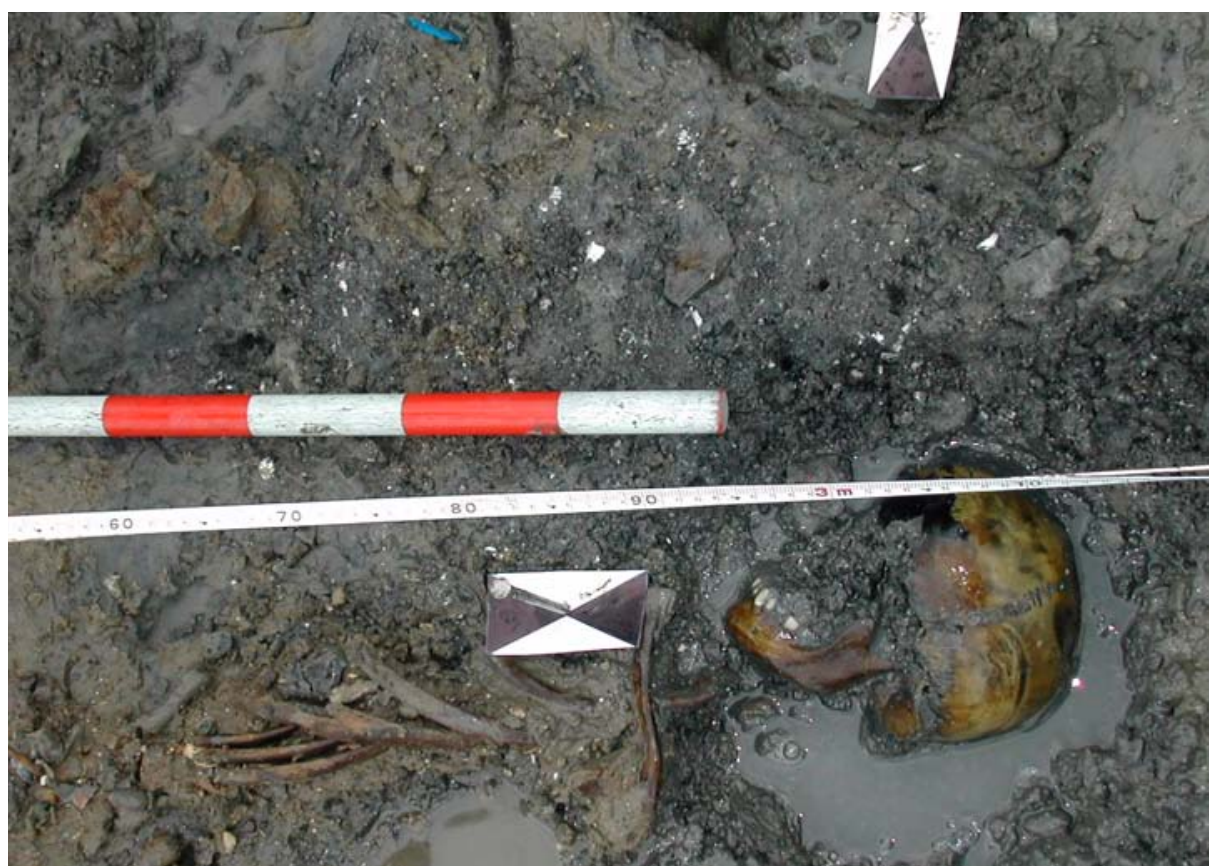

Figure 2 The Chamber's Wharf skeleton

\section{METHODS AND RESULTS}

Replicate bone samples from the left scapula of the skeleton were dated by the Oxford Radiocarbon Accelerator Unit, using methods described by Bronk Ramsey et al. (2000), Brown et al. (1988), and Bronk Ramsey and Hedges (1997). It is not thought that these results were affected by the older contaminant subsequently discovered in this filtration protocol (Bronk Ramsey et al., these proceedings). Two ${ }^{14} \mathrm{C}$ measurements were obtained (OxA-11141-2; $421 \pm 31 \mathrm{BP}$ and $415 \pm 35 \mathrm{BP}$ ) which are statistically consistent according to the $\chi^{2}$ test described by Ward and Wilson $\left(1978 ; \mathrm{T}^{\prime}=0.0\right.$; $\left.\mathrm{n}=1 ; \mathrm{T}^{\prime}(5 \%)=3.8\right)$, and so a weighted mean was taken before calibration $(418 \pm 23 \mathrm{BP})$.

Using the probability method of calibration and INTCAL98, this calibrates to cal AD 1430-1495 (94\% probability; Figure 3a) (Stuiver et al. 1998a; Stuiver and Reimer 1993; Bronk Ramsey 1995 [OxCal v3.5]). There is, however, a considerable complication when considering these results.

The skeleton also produced statistically consistent $\delta^{13} \mathrm{C}$ values of $-17.0 \pm 0.3 \%$ and $-16.7 \pm 0.3 \%$ $\left[\mathrm{T}^{\prime}=0.5 ; \mathrm{T}^{\prime}(5 \%)=3.8 ; \mathrm{n}=1 ;-16.9 \pm 0.3 \% \mathrm{0}\right]$, and consistent $\delta^{15} \mathrm{~N}$ values of $+12.4 \pm 0.5 \%$ and $+12.6 \pm 0.5 \%$ o $\left[\mathrm{T}^{\prime}=0.1 ; \mathrm{T}^{\prime}(5 \%)=3.8 ; \mathrm{n}=1 ;+12.5 \pm 0.4 \% 0\right]$. These results indicate that there is a strong marine component in the ultimate source of carbon in the dated individual (Figure 4).

Methods of estimating this proportion accurately are not well understood (Bayliss et al. 2004), but using the methodology published by Arneborg et al. (1999) in which a simple linear extrapolation is made between a $100 \%$ terrestrial diet $\left(\delta^{13} \mathrm{C}\right.$ value of $-21.0 \%$ ) and a $100 \%$ marine diet $\left(\delta^{13} \mathrm{C}\right.$ value of $-12.5 \%$ ), it can be estimated that $49 \%$ of this individual's protein intake was of marine origin. This information can be used in the interpretation of the ${ }^{14} \mathrm{C}$ results by mixing the atmospheric calibration curve with the marine calibration curve in the proportion suggested by the estimate of marine protein. This has been done using OxCal v3.5 and the methodology outlined in Bronk Ramsey (2001: 356) in which the 2 curves are mixed in user-defined proportions (in this case, $51 \%$ terrestrial, $49 \%$ marine) on the basis of ${ }^{14} \mathrm{C}$ concentration (http://www.rlaha.ox.ac.uk/oxcal/). 


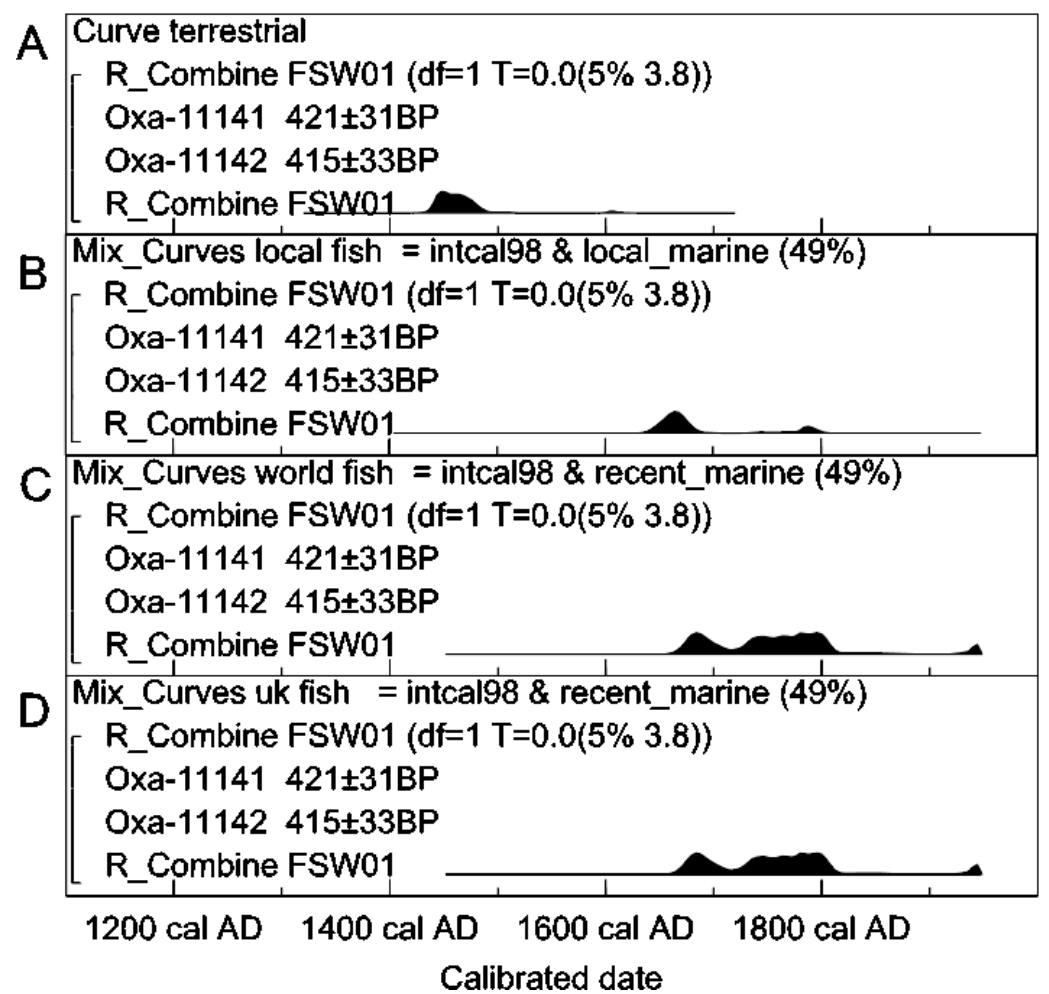

Figure 3 Probability distribution of the calibrated date for the Thames skeleton (a) using the terrestrial curve of Stuiver et al. (1998a); (b) using the marine curve of Stuiver et al. (1998b) and a $\Delta \mathrm{R}$ value of $-5 \pm 40 \mathrm{BP}$; (c) using a $\Delta \mathrm{R}$ value of $112 \pm 37 \mathrm{BP}$; and (d) using a $\Delta \mathrm{R}$ value of $112 \pm 47 \mathrm{BP}$.

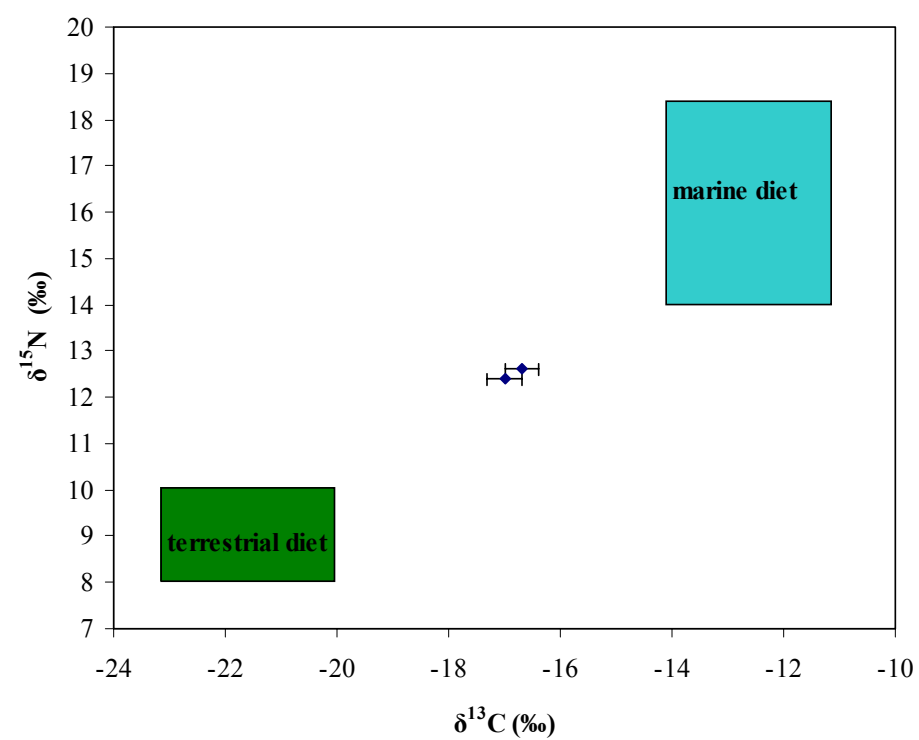

Figure 4 Graph of $\delta^{13} \mathrm{C}$ and $\delta^{15} \mathrm{~N}$ values of bone collagen from Chamber's Wharf, related to the values expected for archaeological populations consuming pure $\mathrm{C} 3$ and marine diets (after Mays 1998). 
Using a $\Delta \mathrm{R}$ value of $-5 \pm 40 \mathrm{BP}$ for the coastal waters off England (Stuiver and Braziunas 1993) and the marine calibration curve of Stuiver et al. (1998b), this provides calibrated date ranges for the burial of cal AD 1635-1695 (77\% probability) or cal AD 1740-1750 (1\%) or cal AD 1760-1805 (17\% probability) (Figure $3 \mathrm{~b}$ ). Using the same methodology, but introducing an error on the estimate of marine protein in the individual's diet $( \pm 10 \%)$, produces the calibrated date shown in Figure 5 b (cal AD 1520-1820 at 95\% probability). The choice of an error of $\pm 10 \%$ is simply illustrative as there are so many unknowns inherent within dietary reconstructions from stable isotope values.

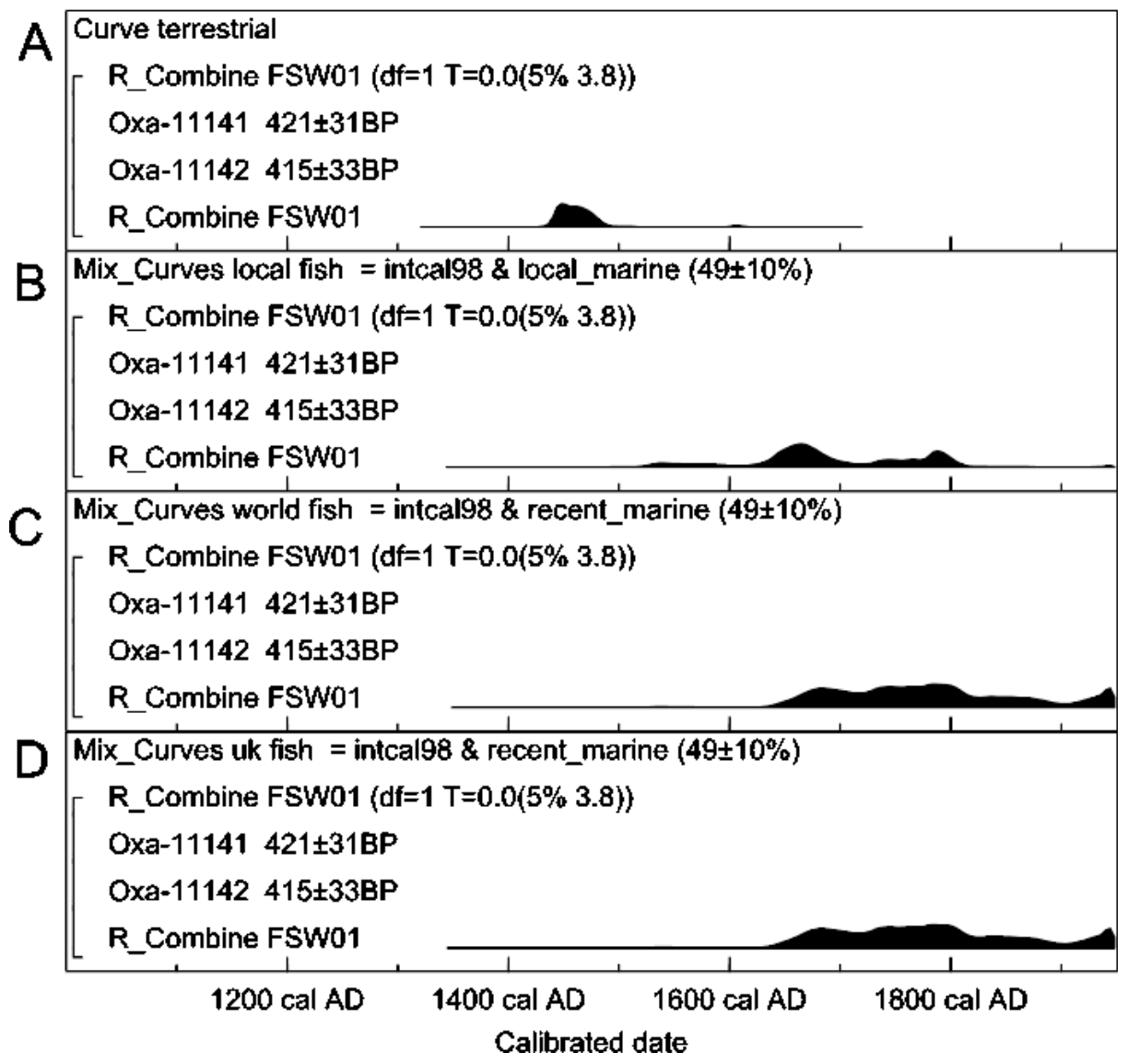

Figure 5 Probability distribution of the calibrated date for the Thames skeleton, with an estimated proportion of marine protein of $49 \pm 10 \%$ : (a) using the terrestrial curve of Stuiver et al. (1998a); (b) using the marine curve of Stuiver et al. (1998b) and a $\Delta \mathrm{R}$ value of $-5 \pm 40 \mathrm{BP}$; (c) using a $\Delta \mathrm{R}$ value of $112 \pm 37 \mathrm{BP}$; and (d) using a $\Delta \mathrm{R}$ value of $112 \pm 47 \mathrm{BP}$.

It is unclear whether the use of an entirely local marine offset is reasonable for a skeleton of this age. Seafaring in northwestern Europe appears to have originated in the Early Bronze Age (Wright et al. 2001), although most fish seem to have been caught locally until the rise of the stockfish market in the medieval period (Heinrich 1986). Cod was certainly being caught and salted by English seamen off Greenland in the early 15th century (Carus-Wilson 1954: Chapter 11). Between the 16th and 18th centuries, the English were largely excluded from the Icelandic fishing grounds by the Danish authorities, and so were forced to develop new fisheries off the North Atlantic coast of America 
(Innis 1940). In contrast, salt herring in late medieval England was largely supplied by traders from the Hanseatic League and derived from the Baltic (Lewis and Runyan 1985: 128-30). By the 17th century, however, the focus of this trade had moved and was controlled by the Dutch from fisheries in the eastern North Sea (Unger 1980). Consequently, from the later medieval period, not only does the scale of the marine component in an individual's diet have to be considered, but also the proportion of marine resources consumed from different sources ${ }^{1}$.

The unexpected ${ }^{14} \mathrm{C}$ age produced by the Chamber's Wharf skeleton meant that the possibility that it is of recent date has to be considered. We have done this by attempting to assess the reservoir age of fish consumed by modern populations. Figure 6 shows the percentage (by weight) of the world marine fish catch in each region of the oceans in 1999 (MAFF 2000), and the approximate marine reservoir correction applicable in each region (after Stuiver and Braziunas 1993). From these statistics, using a simple average of the $\Delta \mathrm{R}$ values of the world fish catch proportional to the weight of fish caught in each region, it can be estimated that the fish consumed in the world in 1999 had an average $\Delta \mathrm{R}$ value of $112 \pm 37 \mathrm{BP}$. Using this value, the ${ }^{14} \mathrm{C}$ age of the Thames skeleton calibrates to cal AD 1660-1820 (92\% probability) or cal AD 1930-1945 (3\% probability) (Figure 3c) or cal AD 1640-1955* (95\% probability) (Figure 5c).

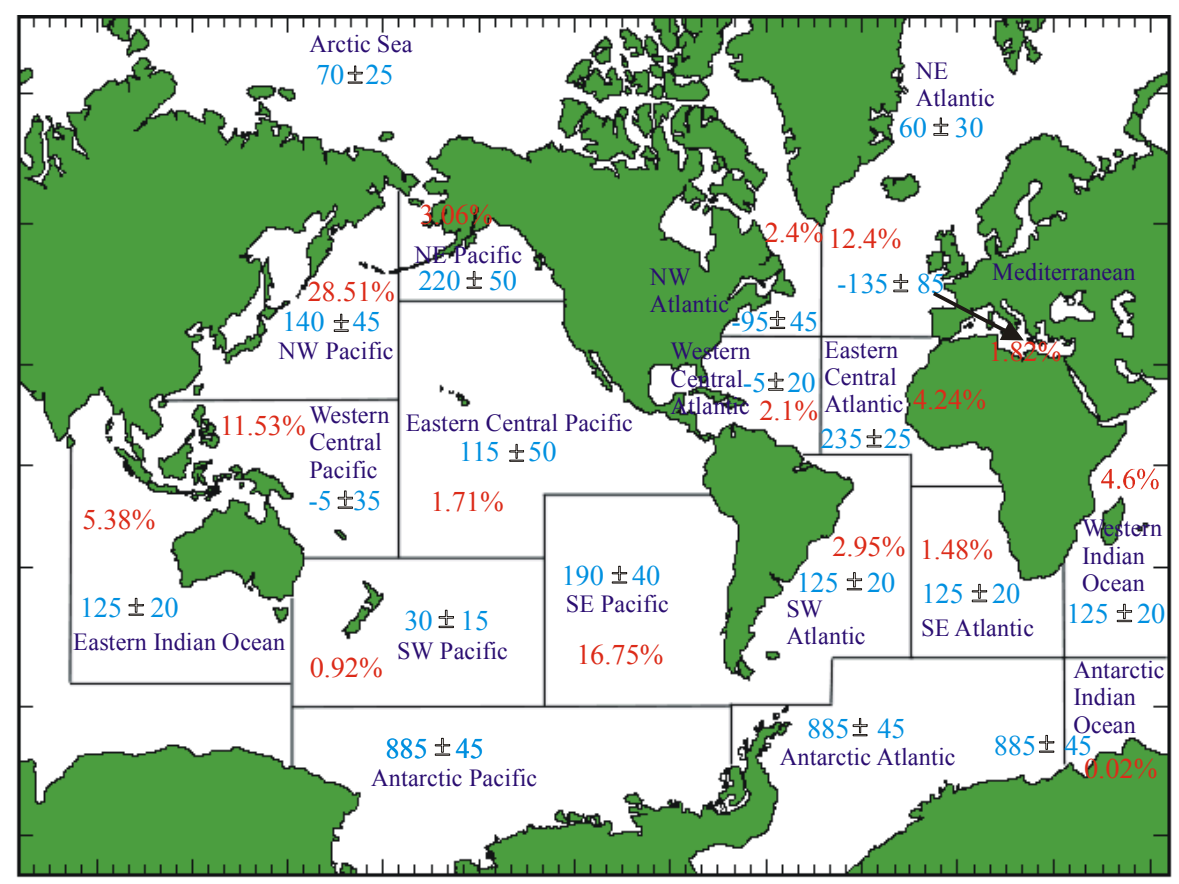

Figure 6 The percentage (by weight) of the world marine fish catch in each region of the oceans in 1999 (MAFF 2000), and the approximate marine reservoir correction applicable in each region (after Stuiver and Braziunas 1993).

\footnotetext{
${ }^{1}$ With the exception of the Salmonids, most marine species which have been widely exploited in England have migration patterns on a regional scale (Taggart 1997; Huse et al. 2002; McKeown 1984). This means that the fish can be expected to have a reservoir age in equilibrium with the region of the sea in which they were caught.
} 
A slightly more sophisticated approach has also been attempted, based on statistics for fish consumed in the UK in 1999. Approximately $20 \%$ was landed in the UK, with the remaining $80 \%$ imported from the regions shown in Table 1 (MAFF 2000). From these statistics, it can be estimated that the fish consumed in the UK in 1999 had an average $\Delta \mathrm{R}$ value of $112 \pm 47 \mathrm{BP}$ (calculated in the same way as above), and so the skeleton again calibrates to cal AD 1660-1820 (92\% probability) or cal AD 1930-1945 (3\% probability) (Figure 3d) or cal AD 1640-1955* (95\% probability) (Figure $5 d)$.

Table 1 Origin of fish consumed in the UK in 1999 (MAFF 2000).

\begin{tabular}{lcc}
\hline Landings by country/trade area & Percentage by weight & Assumed $\Delta \mathrm{R}$ value \\
\hline UK & $20 \%$ & $60 \pm 30 \mathrm{BP}$ \\
European Union & $22 \%$ & $58 \pm 35 \mathrm{BP}$ \\
European Free Trade Area & $27 \%$ & $60 \pm 30 \mathrm{BP}$ \\
Faroe Islands & $7 \%$ & $60 \pm 30 \mathrm{BP}$ \\
Russia & $9 \%$ & $220 \pm 50 \mathrm{BP}$ \\
USA & $2 \%$ & $220 \pm 50 \mathrm{BP}$ \\
Other & $13 \%$ & $112 \pm 37 \mathrm{BP}$ \\
\hline
\end{tabular}

\section{CONCLUSION}

This analysis has shown conclusively that the Chamber's Wharf skeleton is not Neolithic. It has also shown that the body is not sufficiently recent to warrant police investigation. Uncertainty reigns at every stage in attempting to correct these ${ }^{14} \mathrm{C}$ measurements for a marine component in the individual's diet. In these circumstances, any estimate for the absolute date of the skeleton is hazardous, although she certainly died in the 15 th century or later, and perhaps is most likely to have died between $\sim 1650$ and $\sim 1800$.

\section{REFERENCES}

Arneborg J, Heinemeier J, Lynnerup N, Nielsen HL, Rud N, Sveinbjörnsdóttir ÁE. 1999. Change of diet of the Greenland Vikings determined from stable carbon isotope analysis and ${ }^{14} \mathrm{C}$ dating of their bones. Radiocarbon 41(1): 157-68.

Bayliss A, Shepherd-Popescu E, Beavan-Athfield N, Bronk Ramsey C, Cook GT, Locker A. 2004. The potential significance of dietary offsets for the interpretation of radiocarbon dates: an archaeologically significant example from medieval Norwich. Journal of Archaeological Science 31:563-75.

Brown TA. Nelson DE, Vogel JS, Southon JR. 1988. Improved collagen extraction by modified Longin method. Radiocarbon 30(1):171-7.

Bronk Ramsey C. 1995. Radiocarbon calibration and analysis of stratigraphy: the OxCal Program. Radiocarbon 37(2):425-30.

Bronk Ramsey C. 2001. Development of the radiocarbon calibration program. Radiocarbon 43(2A):355-64.

Bronk Ramsey C, Hedges REM. 1997. A gas ion source for radiocarbon dating. Nuclear Instruments and Methods in Physics Research B 29:45-9.

Bronk Ramsey C, Higham TFG, Hedges REM. 2004. Improvements to the pretreatment of bone at Oxford. $R a$ - diocarbon, these proceedings.

Bronk Ramsey C, Pettitt PB, Hedges REM, Hodgins GWL, Owen DC. 2000. Radiocarbon dates from the Oxford AMS system: Archaeometry datelist 30. Archaeometry 42:459-79.

Carus-Wilson EM. 1954. Medieval Merchant Venturers. London: Methuen.

Heinrich D. 1986. Fishing and consumption of cod ( $G a-$ dus morhua L.) in the Middle Ages. In: Brinkhuizen DC, Clason AT, editors. Fish and Archaeology. British Archaeological Reports, International Series 294:4252.

Huse G, Railsback S, Fernö A. 2002. Modelling changes in migration patterns of herring: collective behaviour and numerical domination. Journal of Fish Biology 60:571-82.

Innis HA. 1940. The Cod Fisheries: The History of an International Economy. Toronto: University of Toronto Press. 522 p.

Lewis AR, Runyan TJ. 1985. European Naval and Maritime History, 300-1500. Bloomington: Indiana University Press. 192 p.

Mays S. 1998. The Archaeology of Human Bones. London: Routledge. 256 p. 
Ministery of Agriculture, Fisheries, and Food. 2000. United Kingdom Sea Fisheries Statistics. London: HMSO.

McKeown BA. 1984. Fish Migration. London: Croom Helm Ltd. 224 p.

Stuiver M, Braziunas TF. $1993 .{ }^{14} \mathrm{C}$ ages of marine samples to 10,000 BC. Radiocarbon 35(1):137-89.

Stuiver M, Reimer PJ. 1993. Extended ${ }^{14} \mathrm{C}$ database and revised Calib $3.0{ }^{14} \mathrm{C}$ age calibration program. Radiocarbon 35(1):215-30.

Stuiver M, Reimer PJ, Bard E, Beck JW, Burr GS, Hughen KA, Kromer B, McCormac G, van der Plicht J, Spurk M. 1998a. INTCAL98 radiocarbon age calibration, 24,000-0 cal BP. Radiocarbon 40(3):104183.

Stuiver M, Reimer PJ, Braziunas TF. 1998b. High-preci- sion radiocarbon age calibration for terrestrial and marine samples. Radiocarbon 40(3):1127-51.

Taggart CT. 1997. Bank-scale migration patterns in northern cod. Northwest Atlantic Fisheries Organization (NAFO) Scientific Council Studies 29:51-60.

Unger R. 1980. Dutch herring, technology, and international trade in the seventeenth-century. Journal Economic History 40:253-79.

Ward GK, Wilson SR. 1978. Procedures for comparing and combining radiocarbon age determinations: a critique. Archaeometry 20:19-31.

Wright EV, Hedges REM, Bayliss A, van de Noort R. 2001. New AMS radiocarbon dates for the North Ferriby boats - a contribution to dating prehistoric seafaring in northwestern Europe. Antiquity 75:726-34. 